\title{
Roadmap for improving roof and façade windows in nearly zero-energy houses in
} Europe

Skarning, Gunnlaug Cecilie Jensen; Hviid, Christian Anker; Svendsen, Svend

Published in:

Energy and Buildings

Link to article, DOI:

10.1016/j.enbuild.2016.01.038

Publication date:

2016

Document Version

Peer reviewed version

Link back to DTU Orbit

Citation (APA):

Skarning, G. C. J., Hviid, C. A., \& Svendsen, S. (2016). Roadmap for improving roof and façade windows in nearly zero-energy houses in Europe. Energy and Buildings, 116, 602-613.

https://doi.org/10.1016/j.enbuild.2016.01.038

\section{General rights}

Copyright and moral rights for the publications made accessible in the public portal are retained by the authors and/or other copyright owners and it is a condition of accessing publications that users recognise and abide by the legal requirements associated with these rights.

- Users may download and print one copy of any publication from the public portal for the purpose of private study or research.

- You may not further distribute the material or use it for any profit-making activity or commercial gain

- You may freely distribute the URL identifying the publication in the public portal 


\title{
Roadmap for improving roof and façade windows in nearly zero-energy houses in Europe
}

\author{
Gunnlaug Cecilie Jensen Skarning*, Christian Anker Hviid, Svend Svendsen \\ Technical University of Denmark, Department of Civil Engineering, Brovej, Building 118, 2800 Kgs. Lyngby, Denmark
}

DOI: https://doi.org/10.1016/j.enbuild.2016.01.038

Manuscript accepted for publication in Energy and Buildings 116 (2016) 602-613.

\begin{abstract}
Windows are central for the development of liveable nearly zero-energy homes and require careful consideration. Various studies have indicated that the effect of windows on energy consumption may change significantly with improved building insulation levels. Current guidelines on windows may therefore not apply in very well-insulated buildings, and more up-to-date information is needed about window solutions that are appropriate for the new conditions. This study maps the effect of multiple combinations of window size and basic glazing and frame properties on energy, daylighting and thermal comfort in nearly zero-energy houses located in the European cities Rome and Copenhagen. The aim was to identify options that can support the easy and robust design of future homes with typical use of roof and façade windows. Hourly daylight levels were calculated in DAYSIM, while space heating demand and operative temperatures were calculated in EnergyPlus. The results support previous findings on the limited ability of nearly zero-energy buildings to utilise solar gains. It was found that U-values are becoming increasingly important for the energy performance of windows. The paper sketches the increased flexibility and related possibilities that may appear with improved roof window frame constructions and glazing U-values far lower than currently standard levels.
\end{abstract}

Keywords: Roof windows, Glazing properties, Window size, Orientation, Space heating demand, Climate-based daylighting, Adaptive thermal comfort

\section{Highlights}

- Energy efficient roof windows allowing well-lit comfortable spaces are identified.

- Saving potentials by improving glazing parameters were similar across orientation.

- In Copenhagen extensively improved roof window frame constructions were critical.

- U-values far better than currently standard are suggested in Rome and Copenhagen.

\footnotetext{
${ }^{*}$ Corresponding author

E-mail addresses: gujs@byg.dtu.dk, gunnlaug_cecilie@yahoo.no (G.C.J. Skarning)
} 


\section{Introduction}

Ambitious strategies for energy conservation in the building mass are now a part of European Union legislation. In 2010, a recast of the Energy Performance of Buildings Directive was adopted stating that all new buildings will be required to consume 'nearly zero-energy' by the end of 2020 [1]. It is the responsibility of the member states to specify cost-efficient nearly zero-energy regulations for their buildings in accordance with future energy prices, discount rates and local energy production systems. At the same time, it is important to make sure that decisions made throughout this process will support healthy and comfortable homes. Windows have a considerable and often complex impact on both energy consumption and the indoor environment, so their role in this development is central. A number of studies [2-4] have indicated that the energy performance of windows in residential buildings may change significantly with improved building insulation level, so that what seem common-sense design rules for windows today may not apply for nearly zero-energy buildings or may be superseded by better options. A recent state-of-the-art review by Jelle et al. [5] of existing glazing products and technologies on the market today identified some promising fenestration techniques and options. However, to be able to identify which of these options that will be useful in nearly zero-energy residential buildings, more knowledge is needed about the combined effect of basic glazing properties and window design parameters on energy, daylighting and thermal comfort. Current guidelines suggesting large and clear south-oriented windows may have to be discarded and replaced with up-to-date information about the energy performance of windows in future European homes.

Research on the energy performance of windows in residential buildings used to focus on reduced window sizes and improved U-values, and then started to regard the window as a way of utilising solar energy. With the concept of Zero-Energy Windows [6] and the introduction of new methods for labelling windows in accordance with their net-energy gain [7-9], attention was next drawn to energy-neutral windows with slim frames and high solar energy transmittance (g-value). Studies on the effect of window size and distribution for different glazing types came to the conclusion that large south-oriented windows could reduce space-heating demand, both in colder climates with low solar irradiation [10] and in central to southern European climates [11]. Similarly, a guideline from the UK on sloping roof windows in a typical loft room [12] found slightly larger window sizes for optimum energy use than for daylighting. Furthermore, Jaber \& Ajib [13] showed that optimum window size depends on the thermal properties of the glazing, but for existing triple energy-glazing in the climate of Berlin, they found that increasing the window size facing south always reduced space heating demand. Such rules for energy-neutral windows and their use, however, seem to change in homes with higher insulation levels. Inanici \& Demirbilek [2] investigated the optimum window area facing south in relation to various insulation thicknesses for several climates in Turkey. In general, they found that large windows reduce space heating demand for lightly insulated buildings in cold regions, but that the positive effect of large windows diminishes after a certain level of insulation. Another study by Persson et al. [3] investigated the effect of window size in very well-insulated passive houses in Sweden. They found that the size of south-oriented windows is not as important for heat gains as is traditionally assumed. Moderate heat contributions from south-oriented windows can significantly reduce space 
heating demand, but the heating demand in buildings with this insulation level is so low that very small amounts of the available solar energy can be utilised. They suggest that the focus when designing very well-insulated homes should be on avoiding overheating. These findings were later supported by a study by Vanhoutteghem \& Svendsen [4] of very well-insulated single-family houses in Denmark, which found that windows can be oriented freely in different directions without significantly affecting space heating demand. Both of the latter studies also indicated that the effect of high g-values on space heating demand tends to diminish beyond a certain limit. Similarly, Ihm et al. [14] studied the effect of U- and g-values on the combined space heating and cooling demand in a residential building in a northern and southern climate in Korea, and found that g-values above a certain limit either heavily increased energy consumption or had no effect. As part of the increasing attention to overheating resulting from large south-oriented windows, a number of studies have emphasized the importance of using dynamic control strategies for venting and solar shading to create homes with visual and thermal comfort, while still permitting the efficient use of daylight and solar energy $[15,16]$. Other studies $[4,17]$ have suggested that the importance of dynamic solar shading in low-energy buildings is debatable, due to the reduced need for solar gains. They suggest that glazing with low g-values and solar control coating could be used as a cheaper and more robust means of preventing overheating in such buildings. Furthermore, a recent parametric study by Tsikaloudaki et al. [18] on the energy performance of windows in Mediterranean regions focused on the effect of thermal and optical properties of glazing on the energy demand for cooling.

While for office buildings, there are several examples of studies paying attention to whether the window options investigated are comparable in terms of daylighting and criteria for visual or thermal comfort [19-22], such studies are few for residential buildings. Seen in the light of the tendency that large and clear southoriented windows in very well-insulated dwellings are becoming less important for reducing space heating demand and more critical for thermal comfort, we believe that such investigation is essential also in residential buildings for achieving a balanced overview of future options. The present study therefore focuses on the possibilities of improving the energy performance of window options that provide well-lit and comfortable spaces toward all orientations, to an extent where nearly zero-energy targets can be met in a robust way. In a parametric study of façade window design in single-family houses in Denmark [23], Vanhoutteghem and the present authors have previously reported a method for carrying out such investigation that makes it possible to illustrate and compare the combined effect of multiple combinations of window parameters on energy, daylighting and thermal comfort. The study considered several different room geometries and found that it is difficult to achieve adequate daylighting without overheating in south-oriented rooms deeper than 4-5 m. In the present study, we aim to provide a broader overview of the energy performance of windows in nearly zero-energy houses in Europe. This is why the study includes two geographical locations, Rome and Copenhagen. Our intention is to map and identify the window characteristics that are likely to contribute most to the energy performance of nearly zero-energy houses using roof and façade window options that permit high-quality daylight conditions without overheating when considering a building with reasonable room-layout for daylighting. While our previous study only included façade windows, the present 
study considers a section of a 11/2-storey single-family house that may represent typical use of both roof and façade windows in future residential buildings (Fig. 1). Dynamic solar shading devices were not included in the study. Instead, overheating was reduced by means of glazing products with appropriate g-values and various abilities to separate the transmission of visible light from that of solar energy. The main focus in the paper is the transparent part of the windows, i.e. the glazing, as this faces the most complex challenges in optimising daylighting, thermal comfort and energy consumption at the same time. However, since roof windows are a central part of this study, the investigation also includes variations on the thermal performance of roof window frame constructions (including junctions between roof and window). These account for heat losses similar in level to the heat losses through the whole of the rest of the building envelope of the rooms they are installed in, and may in that way affect the energy consumption of the spaces considerably, which again may influence the possibilities of finding robust solutions for the glazed part.

\section{Methodology}

The building section considered (Fig. 1) consists of two different zone types (A-B) that were modelled as separate units with single-sided daylighting access and venting possibilities. Model A is a side-lit space on the ground floor with façade windows, whereas Model B is a loft room on the $1^{\text {st }}$ floor with 45 -degree-sloped roof windows in one of the two roof surfaces. Studies on the significance of thermal zoning for the prediction of energy performance and the thermal environment $[4,24,25]$ have demonstrated that modelling singlefamily houses as a single zone leads to both underestimation of space heating demand and overheating. As a minimum, these studies suggest that rooms with and without direct solar exposure should be modelled separately. In practice, the various spaces in a real house can take advantage of each other through various amounts of heat and air exchange, but a reasonable starting point for robust development is to identify window solutions that also perform well in houses where such interaction is limited. The floor dimensions for both models were $4 \times 4 \mathrm{~m}$ and the internal volume of each model was $40 \mathrm{~m}^{3}$. These dimensions can be considered a reasonable layout for daylighting. Since the building section considered is located in the middle of the house, where heat losses are smaller than the average for the whole house, the models represent relatively difficult cases for the utilization of solar energy gains and the avoidance of overheating.

\section{$\mathrm{S} \longleftrightarrow \mathrm{N}$}
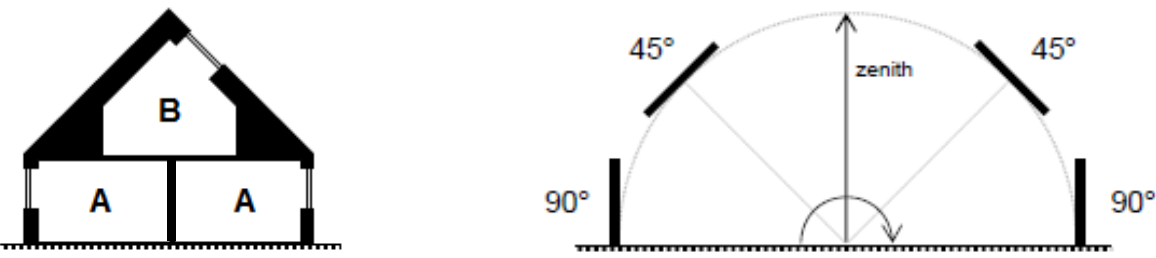

Figure 1: Vertical section of a 11/2-storey single-family house indicating the spaces A-B with typical use of roof and façade windows and the related combinations of window slope and orientation. 


\subsection{Location and climate}

Simulations were performed for two different European climates, based on weather data for Rome and Copenhagen. Outdoor temperatures and solar elevation angles are higher in Rome than in Copenhagen, and the cumulative annual access to daylight and solar irradiation increases almost linearly from the Scandinavian climate in Copenhagen (latitude 55.63) to the South-European climate in Rome (latitude 41.80) [26].

\subsection{Performance parameters for energy, daylighting and thermal comfort}

The study considered homes in which mechanical cooling had not been installed. Energy use was evaluated on the basis of space heating demand alone and was expressed in $\mathrm{kWh} / \mathrm{m}^{2}$ per year. In Denmark, the annual primary energy usage for covering space heating, domestic hot water and electricity for pumps and ventilation in nearly zero-energy residential buildings is defined as no more than $20 \mathrm{kWh} / \mathrm{m}^{2}$, which refers to the energy usage after the primary energy factors of 0.6 for district heating and 1.8 for electricity have been applied. This means that an acceptable space heating demand (or end energy usage for heating) of the building section considered is approximately $10 \mathrm{kWh} / \mathrm{m}^{2}$ per year, when the larger heat losses of rooms in building corners have been taken into account. The goal for the maximum space heating demand was assumed to be the same in Rome [17]. It was further assumed that the occupants were free to use windows for venting, adjust their clothing, and in other ways adapt to indoor conditions. The adaptive thermal comfort (ATC) model in EN 15251 [27] was therefore used to quantify overheating. The ATC model states that the comfortable operative temperature is a function of the running mean outdoor air temperature at the location. With this model, the upper limit for thermal comfort is not a fixed temperature, but a variable temperature that depends on recent temperatures outdoors. In accordance with standard practice procedures in Denmark for documenting thermal comfort in dwellings [28], overheating was deemed to have occurred when operative temperatures in the rooms exceeded the upper comfort limit provided by class II of this model for more than $100 \mathrm{~h}$ per year. For office spaces, Cappelletti et al. [20] showed that solar irradiance through windows may increase the hours of discomfort in positions near window surfaces. Such effects have not been accounted for in this study.

The establishment of reasonable daylight criteria is an issue that is under continuous debate, supported by ongoing research on the effects of daylighting on human health $[29,30]$. For this research, we assumed that the daylighting was acceptable if $75 \%$ of a horizontal plane $0.85 \mathrm{~m}$ above floor level received at least 300 lux in $50 \%$ of the daylight hours. This assumption is in coherence with the diffuse daylight access suggested by Mardaljevic \& Christoffersen [29] and with the recently established recommendations by IES for Spatial Daylight Autonomies in offices [31]. The use of daylight hours instead of office hours for evaluating the occurrence in time, however, implies slightly larger windows than would be found using this metric exactly as defined for offices.

\subsection{Parameter variations}

On the basis of the two room models (A-B), all combinations of the variables given in Table 1 were investigated for both climates. The façade windows were modelled using frame construction A1 (Table 2), whereas 
Table 1: Variables used for parametric analysis.

\begin{tabular}{lll}
\hline Parameter & Rome & Copenhagen \\
\hline Frame construction-façade windows $\left(90^{\circ}\right)$ & A1 & A1 \\
Frame constructions-roof windows $\left(45^{\circ}\right)$ & B1 B2 B3 & B1 B2 B3 \\
Orientation & S N & 5101520253035 \\
Glazing-to-floor ratio $(\%)$ & 5101520253035 & 0.30 .50 .70 .9 \\
Glazing $U$-value $\left(\mathrm{W} / \mathrm{m}^{2} \mathrm{~K}\right)$ & 0.70 .91 .11 .3 & 0.10 .20 .30 .40 .50 .60 .7 \\
Glazing $g$-value $(-)$ & 0.10 .20 .30 .40 .50 .60 .7 & 0.10 .20 .30 .40 .50 .60 .7 \\
Light transmittance $(-)$ & 0.10 .20 .30 .40 .50 .60 .7 &
\end{tabular}

${ }^{a}$ Fraction of internal floor area and for daylighting modelled with $2.5 \%$ increments.

the roof windows were modelled for three different frame constructions (B1-B3). These were: an extremely well-insulated construction not yet in existence (B1), a very well-insulated state-of-the-art-construction (B2) and the frame construction typically used for roof windows today (B3) (Table 2). Hourly illuminance levels were calculated by means of the RADIANCE-based daylighting analysis tool DAYSIM [32] for a sensor point mask-width of $0.2 \mathrm{~m}$. For the calculation of space heating demand and operative temperatures, the building simulation tool EnergyPlus [26] was used in combination with the tool jEPlus [33,34] for parametric analysis. EnergyPlus has been widely validated and is an acknowledged simulation tool that uses the heat balance model to predict thermal loads in buildings. All the rooms were modelled with two windows, consistently distributed and centred on the width, and the windows were always positioned as close to the top edge of the façade or roof surface as possible for optimal diffuse daylight access. In daylight calculations, the depth of all window sills was assumed for simplicity to be $0.45 \mathrm{~m}$ in both climates, although wall and roof thicknesses in the thermal simulations (Table 3) were approximately 0.35 and $0.30 \mathrm{~m}$ in Rome and 0.45 and $0.55 \mathrm{~m}$ in Copenhagen. No external obstructions were taken into account, and the reflectance of surfaces was assumed to be $70 \%$ for walls and ceilings and $30 \%$ for floors. The properties of glazing and frames were modelled in EnergyPlus, using the Simple Glazing System material [35]. This approach allows the thermal and optical properties of windows to be described generically by performance indices such as U-value and g-value where a realistic layer-by-layer description of the glazing is not available. Linear interpolation was used to extract final boundaries for daylighting and thermal comfort from DAYSIM and EnergyPlus output-files.

\subsection{Specifications for building envelope and system properties}

Building envelope and system properties (Table 3 ) were selected on the basis of an earlier study of European nearly zero-energy reference buildings by the present authors [17]. The models assumed ambitious heat recovery efficiency and high-quality construction details. With the thermal properties of construction selected, the annual space heating demand of the building section considered without windows was approximately

Table 2: Thermal properties of the frame constructions investigated for façade and roof windows.

\begin{tabular}{|c|c|c|c|c|c|c|c|}
\hline \multirow[t]{2}{*}{ Window type and slope ${ }^{a}$} & \multirow[t]{2}{*}{ Room model } & \multirow[t]{2}{*}{ Frame construction } & \multicolumn{5}{|c|}{ Frame properties } \\
\hline & & & Width (m) & $U$-value $\left(\mathrm{W} / \mathrm{m}^{2} \mathrm{~K}\right)$ & Psi g (W/m K) & Psi w (W/mK) & Specific heat $\operatorname{loss}^{\mathrm{b}}(\mathrm{W} / \mathrm{K})$ \\
\hline \multirow[t]{2}{*}{ Façade $90^{\circ}$} & A & $\mathrm{A} 1$ & 0.09 & 0.8 & 0.035 & 0.01 & 0.583 \\
\hline & & B1 & 0.09 & 0.5 & 0.025 & 0.01 & 0.399 \\
\hline \multirow[t]{2}{*}{ Roof $45^{\circ}$} & B & B2 & 0.11 & 0.7 & 0.025 & 0.05 & 0.768 \\
\hline & & B3 & 0.09 & 1.5 & 0.050 & 0.10 & 1.460 \\
\hline
\end{tabular}


$4 \mathrm{kWh} / \mathrm{m}^{2}$ in both climates. Windows were assumed to open automatically whenever indoor operative temperatures exceeded the venting set point (Table 3). Heating set-point and design values for internal gains were chosen in accordance with standard practice in Denmark [28]. The heating power to achieve the heating set-point was assumed to be infinite by using the Ideal Loads Air System in EnergyPlus, and the operative temperatures used for evaluation of thermal comfort were achieved using the default Zone Averaged calculation type for the mean radiant temperature of the space [36]. Weather data from the Danish Reference Year [37] were used for Copenhagen, and weather data from the U.S. Department of Energy's homepage [26] were used for Rome.

Table 3: Building specifications for the thermal simulation model.

\begin{tabular}{lll}
\hline & Rome & Copenhagen \\
\hline Constructions & & \\
$U$-value wall $\left(\mathrm{W} / \mathrm{m}^{2} \mathrm{~K}\right)$ & 0.28 & 0.13 \\
$\mathrm{U}$-value roof $\mathrm{a}\left(\mathrm{W} / \mathrm{m}^{2} \mathrm{~K}\right)$ & 0.15 & 0.08 \\
$\mathrm{U}$-value floor $\left(\mathrm{W} / \mathrm{m}^{2} \mathrm{~K}\right)$ & 0.10 & 0.10 \\
System properties and internal loads & & \\
Heating set point $\left({ }^{\circ} \mathrm{C}\right)$ & 20 & 20 \\
Venting set point $\left({ }^{\circ} \mathrm{C}\right)$ & 23 & 23 \\
Infiltration rate $\left(\mathrm{h}^{-1}\right)$ & 0.05 & 0.05 \\
Maximum venting rate $\left(\mathrm{h}^{-1}\right)$ & 4 & 3 \\
Mechanical ventilation rate $\left(\mathrm{h}^{-1}\right)$ & 0.6 & 0.6 \\
Efficiency of heat recovery $(-)$ & 0.9 & 0.9 \\
Loads from people, equipment and lighting $\left(\mathrm{W} / \mathrm{m}^{2}\right)$ & 5 & 5 \\
\hline a Includes linear heat losses. & &
\end{tabular}

\subsection{Coupling of the results - the glazing diagram}

The useful combinations of glazing-to-floor-ratio and glazing g-value, i.e. those that permit $75 \%$ of the space to achieve 300 lux in $50 \%$ of the daylight hours without overheating, can be identified for different window types with different orientations and thermal properties by using the glazing diagram presented in Vanhoutteghem et al. [23]. The diagram is explained in Fig. 2 and basically consists of three layers: one for space heating demand, one for thermal comfort and one for daylighting. When these three layers are put together, the space heating demand of the rooms in $\mathrm{kWh} / \mathrm{m}^{2}$ per year for the combinations of glazing g-value and glazing-to-floor ratio under investigation can be evaluated in relation to a solution space formed by the limits for daylighting and thermal comfort.

In the diagram, each light transmittance value is coupled to a range of g-values based on two selected rules for the relationship between transmittance of light and solar energy. This relationship, also referred to as selectivity for daylight [38], provides information about the ability of a glazing product to separate between the transmittance of visible light and solar energy. Approximately, half the solar irradiation that can pass through glazing is visible light, and it is not physically possible to develop glazing products with a g-value that is less than half the light transmittance [38]. The lower boundary for the g-value (6) is therefore a finite limit that several solar control glazing products on the market today approach quite closely (Fig. 2). The upper limit for daylight efficiency (7) is not a physical limitation and merely indicates optimal products when solar irradiation is desirable. The reader can use this boundary (7), where the g-value 
ENERGY

(1)

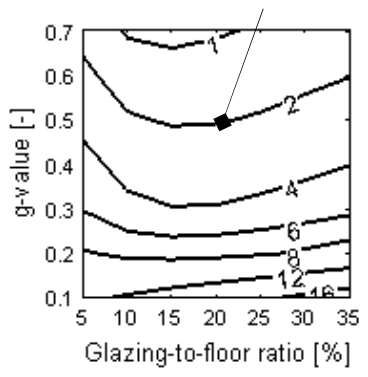

THERMAL COMFORT

(3)

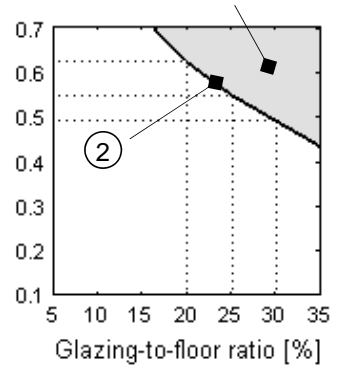

DAYLIGHTING

(4)

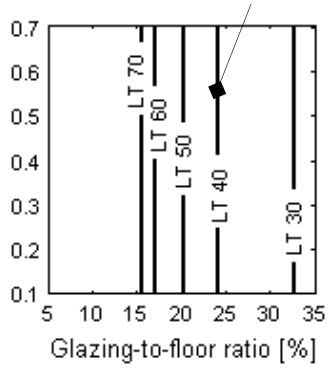

(6)

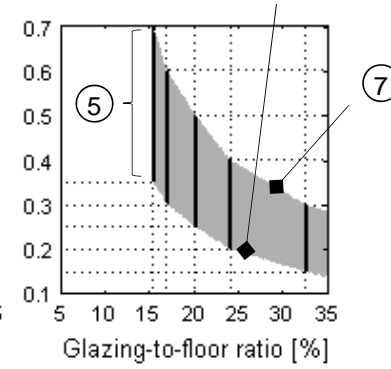

1) Space heating demand in $\mathrm{kWh} / \mathrm{m}^{2}$ per year.

2) Boundary for thermal comfort (max.100 $\mathrm{h}$ per year $>$ limit).

3) Combinations of glazing-to-floor ratio and g-value that will lead to overheating and should be avoided.

4) Lowest possible glazing-to-floor ratios for sufficient daylighting with different light transmittances.

5) Range of available g-values for these light transmittances.

6) Highest physically possible separation between transmittances for visible light and solar energy ( $g$-value equals half the light transmittance).

7) No separation between light and solar energy transmittance ( $g$-value equals the light transmittance). This also tells us the light transmittance that belongs to each vertical line.

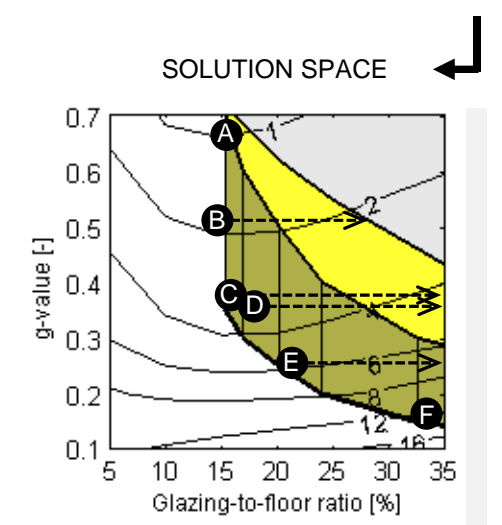

Solution space (in yellow):

Some existing glazing products (A-F) with different properties (U-value/LT/g-value)

are shown in the solution space for daylighting and thermal comfort to exemplify its use:

A-1.1/69/0.67, B-0.5/72/0.51, C-1.0/65/0.39, D-0.5/57/0.36, E-1.0/46/0.26, F:1.0/28/0.17.

The arrows indicate how glazing-to-floor ratio can be increased up to the thermal comfort limit.

Figure 2: Reader's guide to the glazing diagram.

equals light transmittance, to connect the vertical lines showing minimum glazing sizes for daylighting with their respective light transmittance values. Throughout this paper, however, the first line from the left will always correspond to $70 \%$ LT.

\section{Results and discussion}

Figs. 3 [5 illustrate the results achieved in Copenhagen for façade windows (Model A) and for roof windows (Model B) oriented south and north, respectively, for the full range of glazing U-values and frame constructions investigated. Fig. 6 6 illustrates, as an example for Rome, the results for the two window types oriented south and north with a U-value of $0.9 \mathrm{~W} / \mathrm{m}^{2} \mathrm{~K}$ and frame constructions $\mathrm{A} 1$ and B3. The aim of the first section in the following is to introduce the reader to the solution spaces found for the different window types, orientations and climates, and how these should be understood. Based on these useful solutions identified for daylighting and thermal comfort, the next section discusses the potentials for reducing space heating demand by improving glazing $\mathrm{U}$ - and g-value in different parts of the building. Finally, the last section points at two different approaches to the development of window products that meet nearly zero-energy targets and exemplifies thermal properties of glazing and frame that would be required with each of these. 

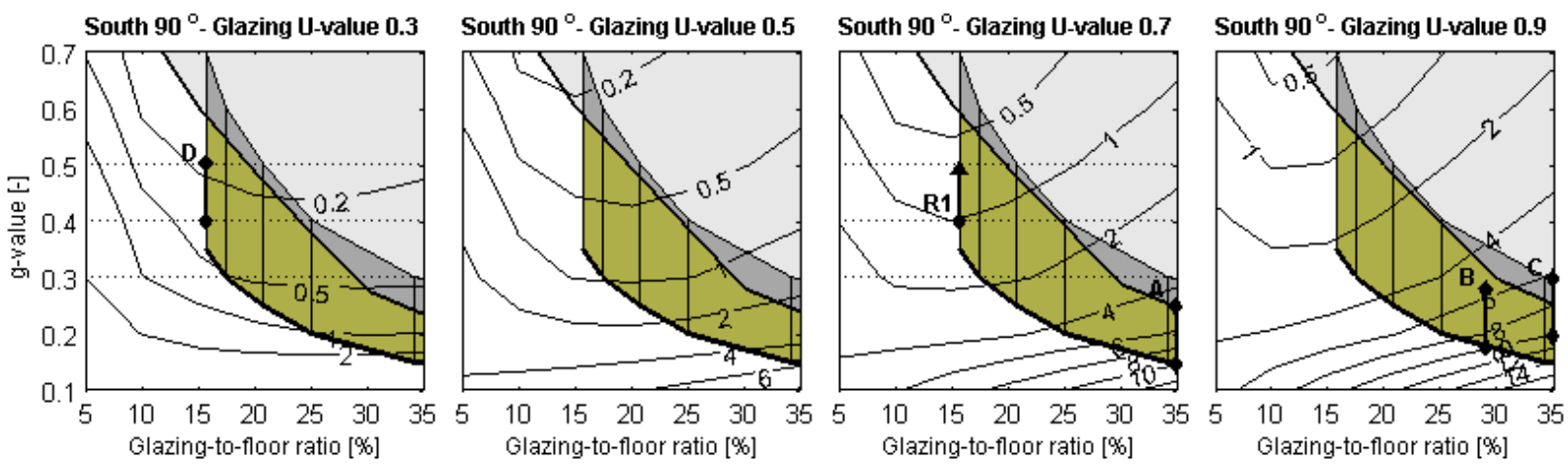

North $90^{\circ}$ - Glazing U-value 0.3

North $90^{\circ}$ - Glazing U-value 0.5
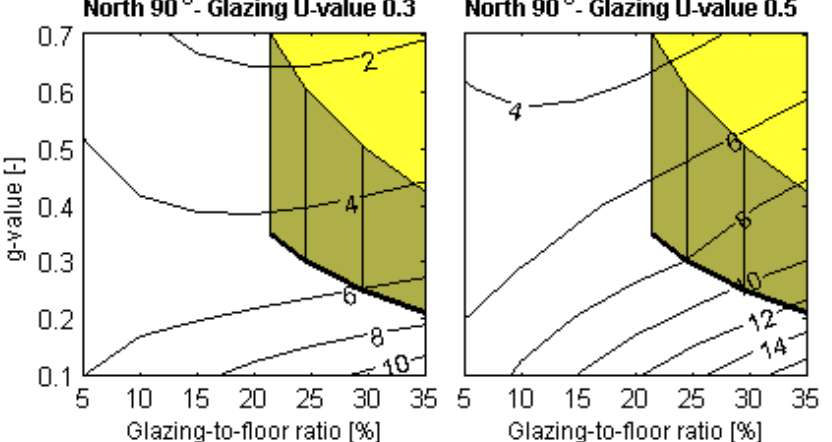

North $90^{\circ}$ - Glazing U-value 0.7

North $90^{\circ}$ - Glazing U-value 0.9
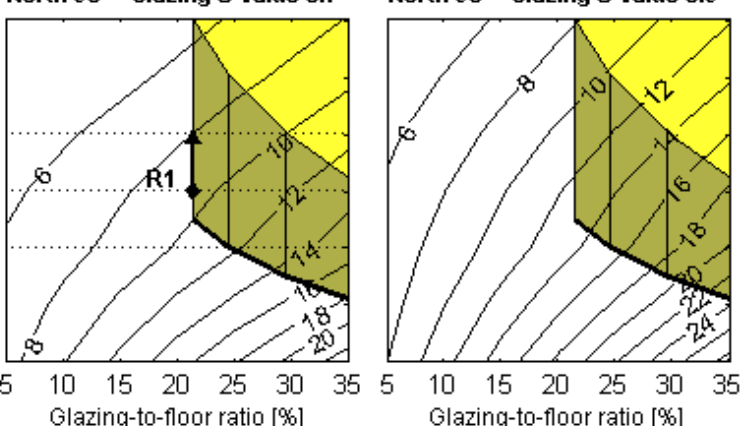

Figure 3: Solution spaces for the façade window in Copenhagen oriented south (top) and north (bottom) with glazing U-values of $0.3-0.9 \mathrm{~W} / \mathrm{m}^{2} \mathrm{~K}$ and frame construction $\mathrm{A} 1$.

\subsection{The useful options for daylighting and thermal comfort}

Daylighting and thermal environment were modelled under realistic outdoor sun and sky conditions. Therefore, Figs. 36 show that every combination of climate, window type and orientation has a solution space with its own boundaries for daylighting and thermal comfort. The design options in the rooms most heavily exposed to direct sun (e.g. a room with south-oriented roof windows in either climate) are limited to small g-values and small glazing-to-floor ratios due to overheating. If the windows are carefully sized for the exact fulfilment of the daylight target, however, it is possible to find options that will fulfil the daylight target without overheating by choosing a glazing with an appropriately low g-value and some selectivity for daylight. For the south-oriented roof windows, one such option might be a glazing corresponding for example to Product E in Fig. 2 with a g-value of 0.26 . With a light transmittance of $46 \%$, this glazing must be dimensioned for glazing-to-floor-ratios of approximately $14-16 \%$ in Copenhagen and 8-10\% in Rome to meet the daylight target without overheating (Line A, Figs. 4 and 6). It should be borne in mind though, that a very narrow solution space still means a large risk of either overheating or less daylighting, so in this case a slightly more flexible option in terms of indoor climate would be to use a north-oriented roof window. With the solar heights in Rome, however, even a north-oriented roof window is exposed to direct sun and has a solution space similar to that of south-oriented façade windows (Fig. 6).

The largest solution spaces were found in rooms with windows that are not exposed to direct sun. Here, no selectivity for daylight is needed (i.e. the g-value can equal LT), and it is possible to use larger glazingto-floor ratios than the minimum for daylighting. For example, for the sloped north-oriented roof window 

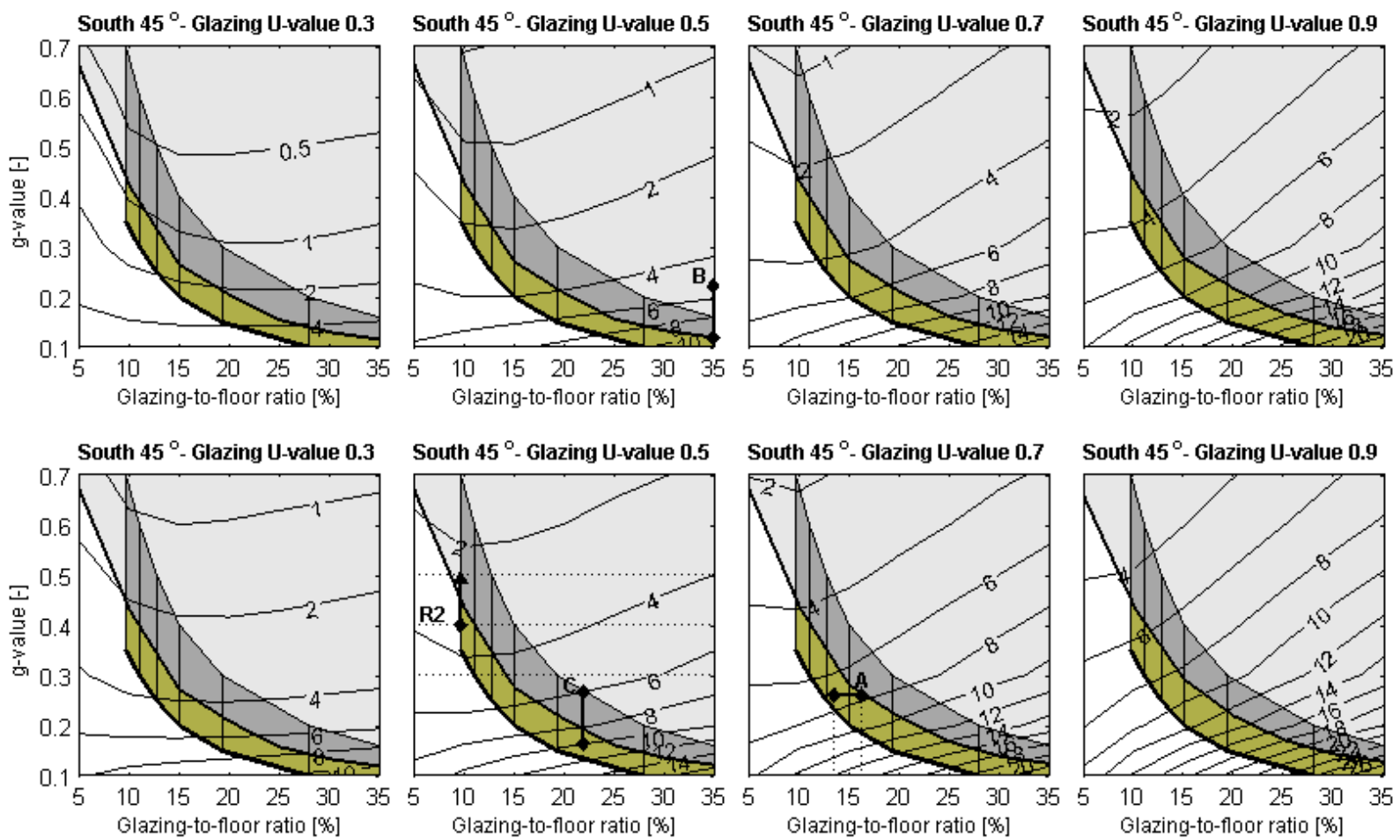

South $45^{\circ}$ - Glazing U-value 0.3
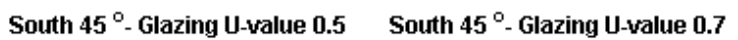

South $45^{\circ}$ - Glazing U-value 0.9
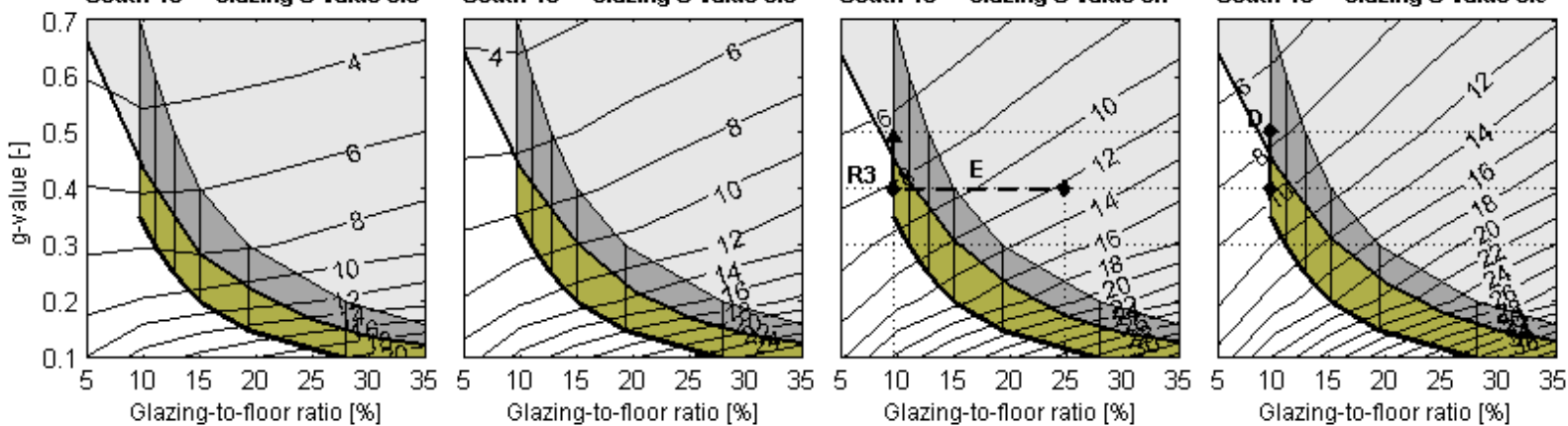

Figure 4: Solution spaces for the 45-degree-sloped roof window in Copenhagen oriented south with glazing U-values of 0.3-0.9 W/ $\mathrm{m}^{2} \mathrm{~K}$ and frame constructions B1 (top), B2 (middle) and B3 (bottom).

in Denmark, a typical option could be a triple energy-glazing, such as Product B in Fig. 2. With this g-value of 0.51, glazing-to-floor ratios can exceed $35 \%$ without overheating (Line A, Fig. 5). This would give significantly more daylighting than targeted, because a glazing-to-floor-ratio of $12-13 \%$ would have been sufficient to meet the daylight target with the light transmittance of $72 \%$ for this product.

\subsection{The importance of glazing $U$ - and g-value for reducing space heating demand}

By studying the contour lines in Figs. 36, it may be seen that the potential savings in space heating demand by changing different parameters for a certain window type and orientation vary with thermal properties of glazing and frame, glazing size and g-value, and tend to diminish as the space heating demand reaches the low levels typically found in solar-exposed rooms for smaller windows with g-values in the range 0.30.5. If, for example, large glazing solutions with energy consumption close to the targeted space heating demand are considered (here $10 \mathrm{kWh} / \mathrm{m}^{2}$ ), increasing glazing g-value by 0.1 reduces energy consumption 

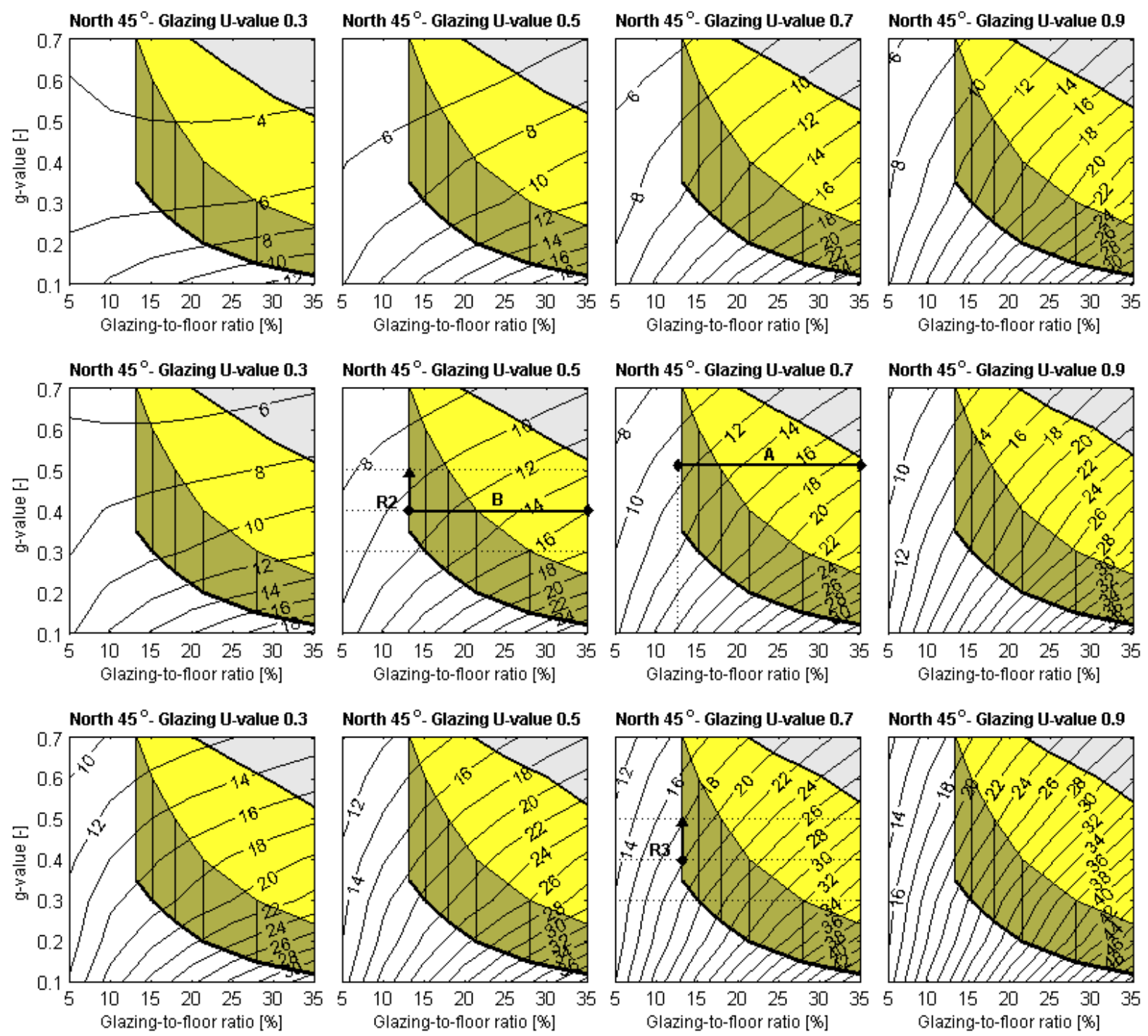

Figure 5: Solution spaces for the 45-degree-sloped roof window in Copenhagen oriented north with glazing U-values of 0.3-0.9 W/ $\mathrm{m}^{2} \mathrm{~K}$ and frame constructions B1 (top), B2 (middle) and B3 (bottom).

by up to $4-5 \mathrm{kWh} / \mathrm{m}^{2}$ per year in the south-oriented rooms with roof and façade windows in Copenhagen (Lines A-C in Fig. 3, and Lines B-C in Fig. 4). If taking a more typical window option with LT 70\% and g-value 0.4 dimensioned for minimum daylighting, however, the energy savings per change in g-value of 0.1 would range from less than $0.2 \mathrm{kWh} / \mathrm{m}^{2}$ per year for the most insulated façade window (Line D, Fig. 3) to at most $2 \mathrm{kWh} / \mathrm{m}^{2}$ per year for the least insulated roof window (Line D, Fig. 44. To compare the energy-saving potentials in glazing U- and g-value for such typical roof and façade windows in building parts with different orientation, Table 4 gives an overview of the savings in space heating demand by either increasing the g-value or decreasing the glazing $\mathrm{U}$-value by 0.1 with basis in three reference points (R1-R3). In Copenhagen, R1 (Fig. 3) represents a façade window option with triple energy-glazing, while R2 and R3 (Figs. 4 and 5) represent roof window options with state-of-the-art thermal properties and the best thermal properties commonly available on the market today, respectively. In Rome, the same references are used, 
South $90^{\circ}$. Glazing U-value 0.9

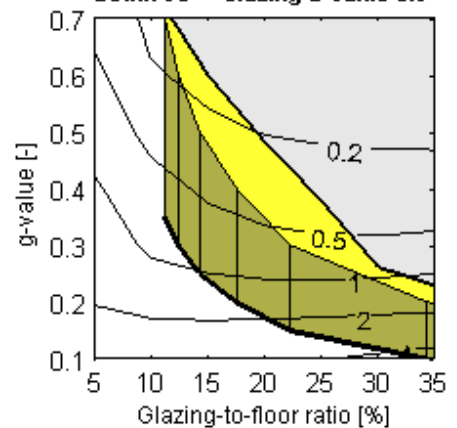

Glazing-to-floor ratio [\%]

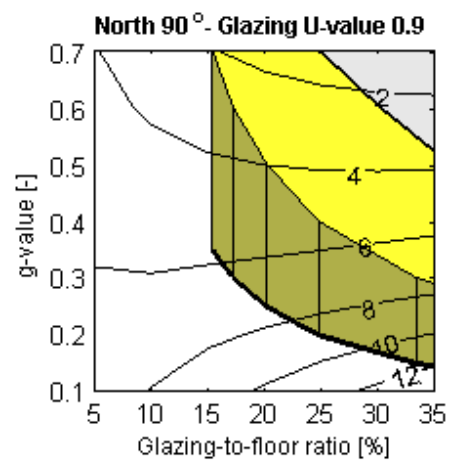

South $45^{\circ}$ - Glazing U-value 0.9

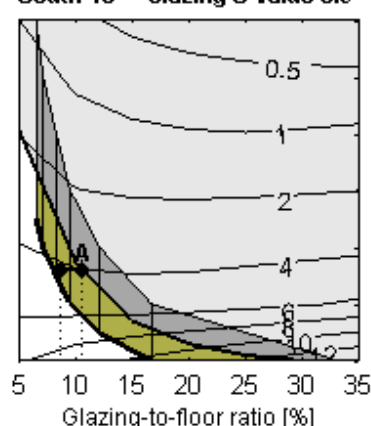

North $45^{\circ}$ - Glazing U-value 0.9

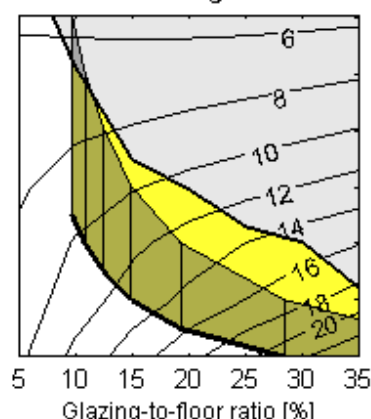

Figure 6: Example of solution spaces for the two window types in Rome oriented south (top) and north (bottom) with glazing U-values of $0.9 \mathrm{~W} / \mathrm{m}^{2} \mathrm{~K}$. The frame constructions are A1 for façade windows (left) and B3 for roof windows (right).

but with higher glazing U-values. All references assume windows with LT $70 \%$ and g-value 0.4 dimensioned for minimum daylighting, and it should be kept in mind that increasing the g-value from 0.4 to 0.5 leads to overheating slightly above the limit in south-oriented rooms with roof windows. Table 4 also indicates the importance of increasing the g-value relative to decreasing the glazing U-value, and the weight of the absolute savings in space heating demand relative to the targeted space heating demand for the building section in total of $10 \mathrm{kWh} / \mathrm{m}^{2}$ per year.

Looking at the relative importance of parameters in south-oriented rooms in Copenhagen, Table 4 shows that increasing the g-value reduced space heating demand by two to three times more than decreasing the

Table 4: Reductions in space heating demand in $\mathrm{kWh} / \mathrm{m}^{2}$ per year by increasing glazing g-value by 0.1 (dg) or decreasing glazing U-value by $0.1\left(\mathrm{dU}_{g}\right.$ ) for some typical references R1-R3 with g-value 0.4 and minimum glazing size for daylighting with LT $70 \%$. The table also indicates the importance of increasing the g-value relative to decreasing the $\mathrm{U}_{\text {-value }}\left(\mathrm{dg} / \mathrm{dU} \mathrm{U}_{g}\right)$ and the weight of the absolute savings per change in each parameter relative to the targeted space heating demand for the building section in total of $10 \mathrm{kWh} / \mathrm{m}^{2}$ per year $\left(\mathrm{E}_{t}\right)$.

\begin{tabular}{|c|c|c|c|c|c|c|c|c|c|c|c|c|}
\hline \multirow{2}{*}{$\begin{array}{l}\text { Window type } \\
\text { and reference }\end{array}$} & & & \multicolumn{5}{|c|}{ Rome } & \multicolumn{5}{|c|}{ Copenhagen } \\
\hline & & & $d g$ & $d U_{\mathrm{g}}$ & $d g / d U_{g}$ & $d g / E_{\mathrm{t}}$ & $d U_{g} / E_{\mathrm{t}}$ & $d g$ & $d U_{g}$ & $d g / d U_{g}$ & $d g / E_{\mathrm{t}}$ & $d U_{g} / E_{\mathrm{t}}$ \\
\hline \multirow[t]{2}{*}{ Façade $90^{\circ}$} & South & R1 & 0.3 & 0.1 & 4.8 & $3 \%$ & $1 \%$ & 0.4 & 0.2 & 2.0 & $4 \%$ & $2 \%$ \\
\hline & North & R1 & 1.2 & 0.5 & 2.4 & $12 \%$ & $5 \%$ & 1.4 & 1.3 & 1.0 & $14 \%$ & $13 \%$ \\
\hline \multirow[t]{4}{*}{ Roof $45^{\circ}$} & South & R2 & 0.6 & 0.1 & 5.9 & $6 \%$ & $1 \%$ & 0.9 & 0.5 & 2.0 & $9 \%$ & $5 \%$ \\
\hline & & R3 & 0.9 & 0.1 & 7.4 & $9 \%$ & $1 \%$ & 1.8 & 0.6 & 2.9 & $18 \%$ & $6 \%$ \\
\hline & North & R2 & 1.0 & 0.4 & 2.6 & $10 \%$ & $4 \%$ & 1.3 & 1.1 & 1.1 & $13 \%$ & $11 \%$ \\
\hline & & R3 & 1.3 & 0.4 & 3.4 & $13 \%$ & $4 \%$ & 2.0 & 1.2 & 1.7 & $20 \%$ & $12 \%$ \\
\hline
\end{tabular}

a Frame type and glazing $U$-value $\left(U_{g}\right)$ in $W / m^{2} K$ for the references. In Rome: $R 1$ (A1, $\left.U_{g} 1.1\right), R 2\left(B 2, U_{g} 0.9\right), R 3\left(B 3, U_{g} 1.1\right)$. In Copenhagen: $R 1$ (A1, $\left.U_{g} 0.7\right)$, R2 (B2, $\left.U_{g} 0.5\right)$, R3 (B3, $\left.U_{g} 0.7\right)$, as indicated in Figs. $3-5$. 
U-value. This means that g-value is still the most important parameter of the two in solar-exposed rooms. These numbers are however low compared with the five to six times more energy that can theoretically be gained by increasing the g-value of a sloped south-oriented window surface, than can be saved by improving the U-value of the surface [8]. This indicates that south-oriented rooms with nearly zero-energy consumption can only utilise approximately half of the solar gains previously assumed fully usable in heating-dominated residential buildings and used as a basis for energy labelling of windows in Denmark [8]. In north-oriented rooms, g-value was 1-1.7 times more important than the U-value.

Comparing the absolute savings in space heating achieved per change in glazing U- or g-value for roofand façade windows with different orientations (Table 4), it may furthermore be seen that the savings by increasing the g-value in south-oriented rooms in Copenhagen account for $4-18 \%$ relative to the targeted space heating demand, while the same savings in north-oriented rooms account for 13-20\%. This means that, even though the g-value is still at least twice as important as the U-value in solar-exposed rooms, the absolute energy savings by improving both parameters are just as important (or more so) for reducing space heating demand in north-oriented rooms as in south-oriented rooms, due to the differences in space heating demand between the two orientations. For façade windows, glazing U- and g-value in north-oriented rooms held approximately three times the saving potential as that of increasing solar gains in south-oriented rooms, while for the loft rooms with roof windows (and an overall larger space heating demand than the ground floor), the saving potential was nearly equal for both orientations.

Another observation related to the importance of $U$ - and g-value is that glazing sizes exceeding a certain optimum increase space heating demand in both north- and south-oriented rooms (Figs. 35). For example, if a g-value of 0.4 for the south-oriented roof window in Copenhagen could be combined with a larger glazing-to-floor-ratio without any risk of overheating, this would not lead to energy savings due to increased access to solar gains, but instead would increase the energy demand for space heating (Line E, Fig. 4). The useful amount of solar irradiation cannot compensate for the increased heat losses with larger windows, even though the glazing U-values considered in this study are low relative to standard practice. This contradicts existing guidelines recommending large and clear south-oriented glazing for energy reduction and indicates that U-value is becoming increasingly important for the energy performance of windows. As glazing U-value decreases (Figs. 3 and 4, the optimum glazing size for space heating may be seen to cover a larger range of glazing-to-floor ratios and move towards larger glazing sizes. In this way, improved U-values can help reduce the negative effect of large window areas. With sufficiently low U-values, the optimum glazing size for space heating will match the solution space for daylighting and thermal comfort so well that window size can be chosen relatively freely with very small effect on energy consumption.

In Rome, the tendencies were similar. With the lower insulation level and the warmer and sunnier climate, the g-value was up to seven times more important than the U-value in solar-exposed rooms. If comparing the saving potential in different building parts, however, reductions in space heating demand per change in both parameters were larger in north-oriented rooms than in south-oriented rooms, but for all room types, the 
g-value was considerably more important than the U-value. Furthermore, window size had only limited effect on space heating demand and could be chosen relatively freely within the boundaries for daylighting and thermal comfort. Similar to the findings by Gasparella et al. [11], large south-facing windows with the lowest U-values could slightly reduce space heating demand, but the tendency was still that large windows towards both orientations slightly increased space heating demand with glazing U-values larger than $0.9 \mathrm{~W} / \mathrm{m}^{2} \mathrm{~K}$.

\subsection{Examples of possible approaches to the development of suitable windows}

Table 5 gives an example of thermal properties of glazing and frame that would be sufficient to meet the energy conservation target at building level with varying degrees of flexibility. The example is based on a reasonable weighting of the space heating demand permitted in different parts of the building. For a north-south-oriented section of the one-storey residential building considered in Vanhoutteghem et al. [23], triple-glazing façade windows with $\mathrm{U}$-value $0.5-0.7 \mathrm{~W} / \mathrm{m}^{2} \mathrm{~K}$ were found sufficient to meet an energy conservation target of $10 \mathrm{kWh} / \mathrm{m}^{2}$ per year with reasonable flexibility. With such façade windows, the average weighted energy consumption of a pair of north-south-oriented rooms at the ground floor in the present study would easily be less than $6 \mathrm{kWh} / \mathrm{m}^{2}$. This permits the loft rooms to consume approximately $16 \mathrm{kWh} / \mathrm{m}^{2}$ per year, given that the $1^{\text {st }}$ floor corresponds to $38 \%$ of the gross floor area of the house. To address the possibility of using north-oriented roof windows, which are the most robust in terms of thermal comfort, as an individual solution for the loft rooms, Table 5 evaluates roof windows with both orientations based on this target. The numbers in brackets, however, indicate the results if the $1^{\text {st }}$ floor was a mix of north- and south-oriented rooms.

The degrees of flexibility used to identify the thermal properties of glazing and frame in Table 5 are based on two different approaches to the development of windows for nearly zero-energy buildings, suggested in the following.

\subsubsection{Well-dimensioned windows with focus on both glazing parameters}

One approach would be to use windows with light transmittances in the higher end and make sure that these are carefully dimensioned for exact fulfilment of the daylighting target. By doing this, window sizes will not be larger than strictly needed for daylighting and g-values can be held relatively high in all room types to favour a low space heating demand. In a solar-exposed room with roof windows, for example, a glazing with LT 70\% that is carefully dimensioned for minimum daylighting may have a g-value of 0.4 and still be within the boundaries for thermal comfort (see e.g. R2-R3, Fig. 4). With the flexible solution space in north-oriented rooms, g-value is not limited by thermal comfort and may be considerably higher. In practice, however, the choice is limited to approximately 0.5 for the triple energy-glazing considered, and even less for the multi-pane glazing solutions needed to approach the $\mathrm{U}$-value of $0.3 \mathrm{~W} / \mathrm{m}^{2} \mathrm{~K}$, which implies relatively small differences in maximum g-value between the two orientations. With the help of such moderate to high g-values, the energy conservation target can be met with a relatively wide range of thermal properties of glazing and frame. For solar-exposed rooms (which includes the north-oriented roof window in Rome), 'Reasonable flexibility' in Table 5 refers to solutions where the energy conservation target can be met with 
Table 5: Acceptable glazing U-values (in the range of $0.7-1.3 \mathrm{~W} / \mathrm{m}^{2} \mathrm{~K}$ in Rome and $0.3-0.9 \mathrm{~W} / \mathrm{m}^{2} \mathrm{~K}$ in Copenhagen) for meeting the targeted space heating demand with varying degrees of flexibility. For roof windows, the U-values in brackets apply if north and south can be averaged.

\begin{tabular}{|c|c|c|c|c|c|c|}
\hline \multirow{2}{*}{$\begin{array}{l}\text { Window type and } \\
\text { frame construction }\end{array}$} & & & \multicolumn{2}{|c|}{ Reasonable flexibility ${ }^{\mathrm{a}}$} & \multicolumn{2}{|c|}{ Full flexibility } \\
\hline & & & Rome & Copenhagen & Rome & Copenhagen \\
\hline Façade $90^{\circ}$ & - & A1 & 1.3 & 0.7 & 0.7 & 0.3 \\
\hline \multirow[t]{6}{*}{ Roof $45^{\circ}$} & South & B1 & $1.3(1.3)$ & $0.9(0.9)$ & $1.3(1.3)$ & $0.7(0.5)$ \\
\hline & & B2 & $1.3(1.3)$ & $0.9(0.9)$ & $1.3(1.1)$ & $0.5(0.3)$ \\
\hline & & B3 & $1.3(1.3)$ & $0.9(0.5)$ & $1.3(0.7)$ & $<0.3$ (« 0.3$)$ \\
\hline & North & B1 & $1.3(1.3)$ & $0.9(0.9)$ & $0.9(1.3)$ & $0.3(0.5)$ \\
\hline & & B2 & $1.3(1.3)$ & $0.7(0.9)$ & $0.7(1.1)$ & $<0.3(0.3)$ \\
\hline & & B3 & $1.3(1.3)$ & $0.3(0.5)$ & $<0.7(0.7)$ & impossible(«0.3) \\
\hline
\end{tabular}

a Energy target met with LT $40-70 \%$ in solar-exposed rooms and LT $60 \%$ with g-value 0.4 in rooms without direct sun.

${ }^{b}$ Energy target met with all combinations of $g$-value and glazing-to-floor ratio within the solution space.

light transmittances in the range 40-70\% without exceeding the boundary for thermal comfort. For the rooms without direct sun 'Reasonable flexibility' is defined as the solutions where the energy conservation target can be met with LT $60 \%$ and g-value 0.4 .

\subsubsection{Focus on extensively improved thermal properties to increase flexibility}

Seen in the light of the reduced significance of solar gains, another approach would be to focus on improving the thermal properties of glazing and frame to a level where the choice of transmittances will no longer be critical for reaching the energy frame. In solar-exposed rooms, where the options for g-value and glazing size are limited by overheating, the use of larger window areas in combination with transmittances at the lower end of the scale can be critical for meeting the energy conservation target. With thermal properties of glazing and frame that are sufficiently low, however, glazing size and transmittances can be selected freely in terms of space heating demand. In this way, it would be possible to use larger glazing areas with the solar control coating and transmittances needed to achieve thermal comfort, which would open up for improved view out and more even daylight distributions, without the need for supplementary dynamic shading devices. This situation where any combination of glazing size and transmittance tends to meet the energy target is referred to as 'Full flexibility' in Table 5 . With the advantages of low U-values discussed in Section 3.2, the improvements in thermal properties of glazing and frame needed to allow 'Full flexibility' will simultaneously increase flexibility regarding window size in both north- and south-oriented rooms. In north-oriented rooms, this flexibility would mean that daylighting could be increased with no limitations regarding overheating and without critically affecting the space heating demand, while in south-oriented rooms this would mean that if window size by different means could be increased without reducing the transmittances, this would only slightly affect space heating demand.

\subsubsection{Thermal properties needed for flexibility in rooms with façade windows}

Studying the façade window options with glazing U-value $0.7 \mathrm{~W} / \mathrm{m}^{2} \mathrm{~K}$, which allow the energy target to be met with 'Reasonable flexibility' in Copenhagen (Fig. 3, and Table 5), it maybe seen that the minimum glazing-to-floor ratios for daylighting with the higher light transmittances correspond well with optimum glazing sizes for space heating demand. Furthermore, with the options that allow 'Full flexibility' (multilayer glazing with U-value $0.3-0.5 \mathrm{~W} / \mathrm{m}^{2} \mathrm{~K}$ ), glazing size can be chosen relatively freely in both north- and 
south-oriented rooms with nearly no effect on space heating demand. In Rome, 'Full flexibility' is achieved with a U-value of $0.7 \mathrm{~W} / \mathrm{m}^{2} \mathrm{~K}$, and for this glazing, large windows are slightly better options for space heating demand than the smaller.

\subsubsection{Thermal properties needed for flexibility in loft rooms with roof windows}

In the loft rooms, space heating demand is naturally higher than for the ground floor. This is both because the room itself has larger heat losses and also because the heat losses are larger through sloped glazing than through vertical glazing. Moreover, heat losses through the roof window frame constructions (including the junction between roof and window) account for a very large part of the space heating demand. Comparing the space heating demand for options that consume less than the targeted $16 \mathrm{kWh} / \mathrm{m}^{2}$ per year in Copenhagen (Figs. 4 and 5), it may be seen that improving thermal properties of frame constructions from the level of B3 to the level of B2, would reduce space heating demand by $3-5 \mathrm{kWh} / \mathrm{m}^{2}$ in south-oriented rooms and 6-7 $\mathrm{kWh} / \mathrm{m}^{2}$ in north-oriented rooms. In Rome, these savings are smaller and in the range $0.5-4 \mathrm{kWh} / \mathrm{m}^{2} \mathrm{per}$ year. For the references (R2-R3), the savings by improving frame constructions in Copenhagen and Rome respectively, are two to three times and 1-1.5 times larger than those identified per change in U- and g-value.

For the glazing-to-floor ratios that give sufficient daylighting, the insulation level of the frame is not seen to affect the consequences of large windows as much as the glazing U-value. The large heat losses of the frame, however, lead to an overall higher space heating demand, which may be critical for whether nearly zeroenergy consumption can be met at building level. Taking as an example, the north-oriented roof window in Copenhagen with standard frame construction (B3), the energy conservation target of $16 \mathrm{kWh} / \mathrm{m}^{2}$ can only just be met with a glazing U-value of $0.5 \mathrm{~W} / \mathrm{m}^{2} \mathrm{~K}$, and even if multi-layer glazing with U-value $0.3 \mathrm{~W} / \mathrm{m}^{2} \mathrm{~K}$ would be available on the market, the energy target would barely be met with reasonable flexibility, taking into account the reduced transmittances with more panes. With the very well-insulated frame construction (B2), however, the target can be met with reasonable flexibility with a glazing U-value of approximately $0.7 \mathrm{~W} / \mathrm{m}^{2} \mathrm{~K}$, and with $\mathrm{U}$-value $0.5 \mathrm{~W} / \mathrm{m}^{2} \mathrm{~K}$ glazing size can be chosen freely when g-values are above 0.4 (Line B, Fig. 5). If the frame construction could be further improved to the level of B1, full design flexibility would be close with a U-value of $0.3-0.5 \mathrm{~W} / \mathrm{m}^{2} \mathrm{~K}$. If the roof window is oriented south, on the other hand, (which increases the risk of overheating), all combinations of U-value and frame construction investigated would be sufficient to meet the energy target. With frame construction B2, however, it would be possible to achieve full flexibility with a U-value of $0.5 \mathrm{~W} / \mathrm{m}^{2} \mathrm{~K}$. These thermal properties are the same as those found to allow free choice of glazing size in north-oriented rooms.

In Rome, the use of a better frame construction than the standard would not add anything for the southoriented window. For the north-oriented roof window, however, which might be the most relevant to consider for thermal comfort, all combinations of U-value and frame investigated are sufficient to meet the target, but full design flexibility could also be within reach by using either the standard frame (B3) in combination with U-values below the investigated range or the improved frame (B2) in combination with a U-value of $0.7 \mathrm{~W} / \mathrm{m}^{2} \mathrm{~K}$. 


\section{Conclusions and outlook}

Considering typical roof and façade window options that provided comfortable and well-lit spaces in all parts of the 11/2-storey building section considered, maximising solar gains in south-oriented rooms was found to have limited potential for reducing space heating demand at building level. In both climates increasing glazing g-value in north-oriented rooms could reduce space heating demand up to several times more than increasing the g-value in south-oriented rooms. In north-oriented rooms in Copenhagen, glazing U-value had approximately the same saving potential as the g-value, while in Rome, the g-value was significantly more important than the U-value for all room types. Improving thermal properties of roof window frame constructions (including junction between roof and window) from the best level commonly available on the market today (B3), to the level of a state-of-the-art construction (B2), reduced space heating demand in Copenhagen and Rome, respectively, by two to three and 1-1.5 times more than could be achieved per change in U- and g-values.

Since maximum g-value is limited either by the technical limitations of the double- or triple energy-glazing considered, or by the risk of overheating, and since increased window size in general does not hold a potential for improving space heating demand, certain thermal properties of glazing and frame are needed to ensure that any part of the building can be designed as comfortable and well-lit spaces, without being critical for achieving nearly zero-energy targets at building level. In Copenhagen, energy conservation targets were met with reasonable flexibility using low-energy triple-glazing with U-value $0.5-0.7 \mathrm{~W} / \mathrm{m}^{2} \mathrm{~K}$. Standard frame construction (B3) was sufficient in rooms with south-oriented roof windows, while north-oriented roof windows would need frame constructions with significantly better thermal properties than are currently standard practice in order to be considered an independent option for the loft rooms. In Rome, standard frame construction and the range of glazing $\mathrm{U}$-value investigated $\left(0.7-1.3 \mathrm{~W} / \mathrm{m}^{2} \mathrm{~K}\right)$, was sufficient to meet the targeted space heating demand in all cases.

By considering several combinations of glazing size and transmittances, this paper also points at the possibility of further improving thermal properties of glazing and frame to a level where the choice of transmittances will no longer be critical for nearly zero-energy targets. In general, products with solar control coating (i.e. g-values as low as possible compared with the light transmittance) are the products that can maximise daylighting the most in solar-exposed rooms without overheating, even if dynamic solar shading or improved venting strategies would allow larger glazing sizes without reducing the transmittances. Less focus on maximising the g-values in solar exposed rooms would open up for the use of such solar control-coated products, and permit the use of a number of existing glazing techniques with low transmittances that could provide larger architectural freedom without overheating in an easy and robust way. In Copenhagen, such flexibility would require considerably lower glazing U-values than are state-of-the-art today (at least multilayer glazing with $\mathrm{U}$-value $0.3-0.5 \mathrm{~W} / \mathrm{m}^{2} \mathrm{~K}$ ). Additionally, thermal properties of frame construction would have to be improved to the level of (B2) for south-oriented roof windows and to the ideal level of (B1) for north-oriented roof windows. In Rome, the same flexibility was achieved with glazing U-values of approxi- 
mately $0.7 \mathrm{~W} / \mathrm{m}^{2} \mathrm{~K}$ and standard frame constructions, but for north-oriented roof windows either thermal properties of glazing or frame would have to be slightly improved. These properties are considerably better than standard practice today, but realistic.

Focusing on windows that are just enough well-insulated to meet the energy target using as high g-values as possible, is not a sufficient approach to help increase flexibility regarding window size. Moreover, thermal properties of glazing and frame are the only parameters that are robust even under difficult conditions. For example, if windows are heavily obstructed by the surroundings, useful transmittances are reduced and larger window sizes are needed for sufficient daylighting. The same would be the case if considering buildings with a more difficult room layout for daylighting. For windows to be robust even under such conditions, glazing U-values and frame constructions that allow reasonable to full flexibility in the choice of glazing size and transmittances are recommended. Because window solutions that add more energy to the building than they consume are becoming increasingly difficult to achieve, we suggest that instead of continue focusing on maximising solar gains in south-oriented rooms, which does not hold a particularly large saving potential anymore at building level and increases the risk of overheating, focus in future window development should be on reaching insulation levels of glazing and frame that increase the chances that no room types will be critical for the nearly zero-energy targets at building level. In general, it was found that the thermal properties that allowed window sizes to be selected freely in north-oriented rooms using moderate g-values, allowed nearly free choice of transmittance and glazing size in south-oriented rooms.

The values reported for thermal properties of glazing and frame in this study, are an outcome of the specific building section considered, which consists of rooms with identical floor plans, modelled as separate spaces with either roof- or façade windows oriented north or south, thus the effect of windows with different slope and orientation in the same room or heat- and air-exchange between zones is not taken into account. More case-specific descriptions of floor plan and user patterns would also affect the results. Furthermore, for the case of Rome, the targeted space heating demand and building insulation level can only be seen as an example of a thinkable nearly zero-energy context. For Copenhagen, however, where targets for nearly zero-energy consumption in residential buildings have been specified, and where the case considered assumes rather ambitious insulation levels, air-tightness and ventilation heat recovery, the thermal properties of glazing and frame suggested in this study may be seen as rather strong indications of a need for glazing U-values of at least state-of-the art level and extensively improved roof window frame constructions.

The present study showed that using the climate-based daylight target suggested by IES [31] for a dwelling with operable windows and moderate venting options, it was possible to achieve thermal comfort according to the ATC model in both a northern and a southern European climate, even without dynamic shading devices or mechanical cooling. Further research on the effect of dynamic solar shading on daylighting and thermal comfort and the achievable venting rates for different building scenarios is needed to determine whether the relatively narrow solution spaces found in south-oriented rooms can be considered acceptable options in terms of indoor climate. 


\section{Acknowledgements}

The authors would like to thank VELUX A/S for their financial support for this research.

\section{References}

[1] European Union, Directive 2010/31/EU of the European Parliament and of the Council of 19 May 2010 on the Energy Performance of Buildings (recast), Official Journal of the European Union, 18/06/2010, Strasbourg, France, 2010.

[2] Inanici, M.N., Demirbilek, F.N. Thermal performance optimization of building aspect ratio and south window size in five cities having different climatic characteristics of Turkey. Building and Environment 35 (2000) 41-52.

[3] Persson, M-L., Roos, A., Wall, M. Influence of window size on the energy balance of low energy houses. Energy and Buildings 38 (2006) 181-188.

[4] Vanhoutteghem, L., Svendsen, S. Modern insulation requirements change the rules of architectural design in low-energy homes. Renewable Energy 72 (2014) 301-310.

[5] Jelle, B.P., Hynd, A., Gustavsen, A., Arasteh, D., Goudey, H., Hart, R. Fenestration of today and tomorrow: A state-of-the-art review and future research opportunities. Solar Energy Materials \& Solar Cells 96 (2012) 1-28.

[6] Arasteh, D., Goudey, H., Huang, J., Kohler, C., Mitchell, R. Performance Criteria for Residential Zero Energy Windows. ASHRAE Transactions 113 (2007) 176-185.

[7] Svendsen, S., Kragh, J., Laustsen, J.B. Energy performance of windows based on the net energy gain. Proceedings of the $7^{\text {th }}$ Symposium on Building Physics in the Nordic Countries, Reykjavik, June 13, 2005.

[8] Nielsen, T.R., Duer, K., Svendsen, S. Energy performance of glazing and windows. Solar Energy 69 (2001) 137-143.

[9] Karlsson, J., Karlsson, B., Roos, A. A simple model for assessing the energy performance of windows. Energy and Buildings 33 (2001) 641-651.

[10] Peuhkuri, R., Pedersen, S., Tschui, A. Principles and specific challenges of very low-energy houses in colder climates and corresponding residential concept houses. Presented at the $4^{\text {th }}$ Nordic Passive House Conference, 17-18 Oct. 2011, Helsinki, Finland. NorthPass 2012 online at: northpass.ivl.se/ publicationsfromnorthpass/articles/articles.5.5c577972135ee95b5638000912.html 
[11] Gasparella, A., Pernigotto, G., Cappelletti, F., Romagnoni, P., Baggio, P. Analysis and modelling of window and glazing systems energy performance for a well-insulated residential building. Energy and Buildings 43 (2011) 1030-1037.

[12] Robertson, S., Thompson, M. Guidelines for sizing roof windows. WITpress 2006 online at: www. witpress.com/elibrary/wit-transactions-on-the-built-environment/86/16363.

[13] Jaber S., Ajib, S. Thermal and economic windows design for different climate zones. Energy and Buildings 43 (2011) 3208-3215.

[14] Ihm, P., Park, L., Krarti, M., Seo, D. Impact of window selection on the energy performance of residential buildings in South Korea. Energy Policy 44 (2012) 1-9.

[15] Active House Alliance. Active house - the specifications for residential buildings. $2^{\text {nd }}$ edition, Brussels, Belgium, 2013. Available at: www.activehouse.info/about-active-house/specification.

[16] Foldbjerg, P., Asmussen, T. Using ventilative cooling and solar shading to achieve good thermal environment in a Danish Active House. The REHVA European HVAC Journal 50 (3) (2013) 36-42.

[17] Skarning, G.C.J., Svendsen, S., Hviid, C.A. Investigation and description of European buildings that may be representative for "nearly zero" energy single family houses in 2020. Proceedings of the CISBAT Conference, Lausanne, 4-6 September 2013, 247-252.

[18] Tsikaloudaki, K., Laskos, K., Theodosiou, T., Bikas, D. The energy performance of windows in Mediterranean regions. Energy and Buildings 92 (2015) 180-187.

[19] Ochoa, C.E., Aries, M.B.C., van Loenen E.J., Hensen, J.L.M. Considerations on design optimization criteria for windows providing low energy consumption and high visual comfort. Applied Energy 95 (2012) $238-245$.

[20] Cappelletti, F., Prada, A., Romagnoni, P., Gasparella, A. Passive performance of glazed components in heating and cooling of an open-space office under controlled indoor thermal comfort. Building and Environment 72 (2014) 131-144.

[21] Lee, J.W., Jung, H.J., Park, J.Y., Lee, J.B., Yoon, Y. Optimization of building window system in Asian regions by analyzing solar heat gain and daylighting elements. Renewable Energy 50 (2013) 522-531.

[22] Motuziene, V., Juodis, E.S. Simulation based complex energy assessment of office building fenestration. Journal of Civil Engineering and Management 16:3 (2010), 345-351. 
[23] Vanhoutteghem, L., Skarning, G.C.J., Hviid, C.A., Svendsen, S. Impact of façade window design on energy, daylighting and thermal comfort in nearly zero-energy houses. Energy and Buildings 102 (2015) $149-156$.

[24] Yohanis, Y.G., Norton, B. A comparison of the analysis of the useful net solar gain for space heating, zone-by-zone and for a whole-building. Renewable Energy 19 (2000) 435-442.

[25] O'Brian, W., Athienitis, A., Kesik, T. Thermal zoning and interzonal airflow in the design and simulation of solar houses: a sensitivity analysis. Journal of Building Performance Simulation 4 (2011) 239-256.

[26] US Department of Energy, EnergyPlus Energy simulation software, http://apps1.eere.energy.gov/ buildings/energyplus/ (accessed 15.07.2015).

[27] European Standard EN 15251. Indoor Environmental Input Parameters for Design and Assessment of Energy Performance of Buildings Addressing Indoor Air Quality, Thermal Environment, Lighting and Acoustics, 2007, CEN.

[28] Aggerholm, S.O. and Grau, K.E. SBi-anvisning 213: Bygningers energibehov - Beregningsvejledning, $3^{\text {rd }}$ edition, Danish Building Research Institute, Aalborg University, 2014 (in Danish).

[29] Mardaljevic, J., Christoffersen, J. A roadmap for upgrading national/EU standards for daylight in buildings. Proceedings of the CIE Centenary Conference, Paris, 15-16 April 2013, 178-187.

[30] Andersen, M., Mardaljevic, J., Lockley, S.W. A framework for predicting the non-visual effects of daylight - Part I: photobiology-based model. Lighting Research and Technology, 44 (2012) 37-53.

[31] IESNA, LM-83-12, IES Spatial Daylight Autonomy (sDA) and Annual Sunlight Exposure (ASE), New York, NY, USA, IESNA Lighting Measurement, 2012.

[32] DAYSIM, Advanced daylight simulation software. http://daysim.ning.com/ (accessed 15.07.2015).

[33] Zhang, Y., Korolija, I. Performing complex parametric simulations with jEPlus, in: SET2010 - $9^{\text {th }}$ International Conference on Sustainable Energy Technologies, 24-27 August 2010, Shanghai, China.

[34] Zhang, Y. 'Parallel' EnergyPlus and the development of a parametric analysis tool, in: IBPSA BS2009, 27-30 July 2009, Glasgow, UK, 1382-1388. 
[35] Arasteh, D., Kohler, C., Griffith, B. Modeling Windows in Energy Plus with Simple Performance Indices. Report LBNL-2804E, Lawrence Berkeley National Laboratory, October 2009.

[36] U.S. Department of Energy, EnergyPlus Engineering reference. Published online 2014. Available at: http://apps1.eere.energy.gov/buildings/energyplus/pdfs/engineeringreference.pdf.

[37] Jensen, J.M., Lund, H., Design Reference Year, DRY - et nyt dansk referenceår. Technical Report lfv-281, Technical University of Denmark, 1995 (in Danish).

[38] Glasfakta 2012: Et praktisk hjælpemiddel for valg af bygningsglas. Pilkington Danmark A/S, Denmark, 2012 (in Danish). 